\title{
Infection, colonization and extrusion of Metarhizium anisopliae (Metsch) Sorokin (Deuteromycotina: Hyphomycetes) in pupae of Diatraea saccharalis F. (Lepidoptera: Crambidae)
}

\author{
L. C. L. Schneider, C. V. Silva, J. A. Pamphile and H. Conte* \\ Department of Cell Biology and Genetics, CCB, Maringá University State, Avenida Colombo 5790, BI. H67, \\ Maringá PR. Brazil, CEP - 87020-900, Brazil.
}

Accepted 6 August, 2012

\begin{abstract}
The strains MT and E9 of Metarhizium anisopliae were found to be effective in causing the morphological changes in pupae of Diatraea saccharalis of different ages. However, during the treatment with the two strains, it was observed that there was a decrease in the longevity of old pupae and adults that emerged from old and young pupae. The adults that emerged died $24 \mathrm{~h}$ later and were totally covered by the pathogen's mycelium. Regarding the mortality of pupae of different ages, but in relation to the abnormalities, the pre-pupae were found to be more susceptible. The morphological alterations observed in the cuticle and in the internal tissues of the pupae were analyzed using a stereomicroscope, a light microscope and a scanning electron microscope. The adhesion stage and formation of the appressorium happened $18 \mathrm{~h}$ after the infection, occasioning black spots and depressions in the cuticle of young and old pupae. In pre-pupae, the sclerotization was not observed and the fungus acted faster and more effectively, thereby, achieving $100 \%$ mortality. The colonization of the pathogen was observed in young pupae between 48 and $120 \mathrm{~h}$. The alterations were observed in the fat body, digestive system and musculature; moreover, several vacuoles were noticed inside the pupae. The extrusion happened after $120 \mathrm{~h}$, presenting the mycelial growth upon the pupae cuticle and further sporulation upon the corpses. The morphological alterations that took place during the development of $M$. anisopliae suggest the possible causes for the mortality of the pupae of $D$. saccharalis.
\end{abstract}

Key words: Biological control, entomopathogenic fungi, pupal stage, sugarcane borer.

\section{INTRODUCTION}

The mycopathogen Metarhizium anisopliae (Metsch.) Sorokin and other entomopathogenic fungi are widely known and used as biological control agents for several agricultural plagues of considerable economical expression. This pathogen presents infection and colonization mechanisms similar to those found in the arthropods in their several stages of development and the stages are as follows: adhesion, germination, formation of the appressorium, penetration, extrusion and sporulation upon the corpse (Vicentini and Magalhães,

${ }^{*}$ Corresponding author. E-mail: hconte@uem.br. Tel: 55-443261-4466. Fax: 55 - 44-3011-4346.
1996; Alves et al., 2002; Garcia et al., 2005; Bai et al., 2010).

During the colonization, the fungus caused physiological disturbances inside the insect which started on the integument and later reached the circulatory, reproductive, respiratory, nervous, and digestive systems, and interacted with the insect's immune mechanisms; this interaction was very complex and specific (Hajek and Leger, 1994; Hegedus and Khachatourians, 1996; Alves and Pereira, 1998). The penetration of entomopathogenic fungus through the insect's cuticle presents advantages over other pathogens such as virus and bacteria whose infection occurs through oral pathway, mesenteron (Ferron, 1978; Alves, 1998). In the pupal stage, the insect does not eat 
and can be affected by entomopathogenic fungi that penetrate through the cuticle. Several orders of insects such as Diptera, Coleoptera, and Thysanoptera are infected in their pupal stage (Watt and Lebrun, 1984; Ekesi and Maniania, 2000; Destéfano et al., 2005; Ansari et al., 2007); however, the infection and colonization mechanism of the pathogen in this stage has been described a little in Lepidoptera, but has not been demonstrated in larvae (Revathi et al., 2011; Hussein et al., 2012).

The sugarcane borer Diatraea saccharalis $F$. (Lepidoptera: Crambidae) is an insect of great economic interest for the sugar-alcohol industry, because when it occurs in sugarcane plantations, it causes several damages (Roc et al., 1981). Chemical control of the sugarcane borer is not recommended and biological control is the most common method of suppressing $D$. saccharalis (William et al., 1969, Guagliumi, 1973). Biological control of the sugarcane borer larvae by strains of $M$. anisopliae and Beauveria bassiana has been achieved (Alves et al., 1984, 1985). In this study, we have evaluated the action of the two strains of $M$. anisopliae in pupae and $D$. saccharalis of different ages, and the morphological alterations in the integument and internal organs during the processes of infection, colonization, and extrusion of the fungus.

\section{MATERIALS AND METHODS}

For the acquisition of pre-pupae and pupae, larvae of $D$. saccharalis were placed on artificial diet (Hensley and Hammond, 1968) and kept in a laboratory, under the following conditions: 25 $\pm 1^{\circ} \mathrm{C}$, relative humidity of $70 \pm 10 \%$, and $12 \mathrm{~h}$ photoperiod. The prepupae and pupae of different ages were taken out of the diet and separated into the following groups: pre-pupae (PP, intermediary stage between the caterpillars and the pupae and beginning of the melanization and chitinization), young pupae (YP, from one to six days of development) and old pupae (OP, from 7 to 14 days of development).

\section{Acquisition of the spores}

The isolates MT and E9 of $M$. anisopliae were obtained from the micro-organisms Laboratory, ESALQ-USP and was originally isolated from Deois sp. (Hemiptera, Cercopidae) in Mato Grosso (MT) and Espirito Santo (E9), Brazil and cultured in Petri dishes containing complete medium (CM) (Pontecorvo et al., 1953), and incubated at $28 \pm 1^{\circ} \mathrm{C}$, with a relative humidity of $70 \pm 10 \%$ for $12 \mathrm{~h}$ photoperiod for approximately 10 days. The conidial suspension was prepared by adding $10 \mathrm{ml}$ of an aqueous solution of Tween $80^{\circledR}$ $\left(0.01 \% \mathrm{v} \mathrm{v}^{-1}\right)$ in the dishes containing the isolates. The suspension was removed, filtered in sterilized gauze and the concentration was standardized in $10^{7}$ conidia/ml with the aid of a Neubauer chamber.

\section{Topic treatment}

12 individuals were used for each treatment (strain MT, E9, and the control group), using three repetitions $(n=36)$, totalizing 108 individuals per group. Approximately, $100 \mu$ of conidial suspension were sprayed topically on each organism and the control group was sprayed with the same amount of sterile distilled water. After the treatment, the individuals were all placed into polyethylene containers containing moistened cotton wad, covered with filter paper, and kept under the experimental condition as mentioned above.

\section{A stereomicroscopic analysis}

The observations were done in the morning every $24 \mathrm{~h}$ until the $9^{\text {th }}$ day after the treatment $(216 \mathrm{~h})$ using a Zeiss stereomicroscope (Carl Zeiss, Jena, Germany) and photographed using a TRON 5.2 MG digital camera. The abnormality, mortality, and longevity rates were recorded for further analyses. The emergence and mortality rates of adults of the groups treated were also considered for further analyses.

\section{Statistical analysis}

The experimental data of the groups PP, YP and OP were compared applying the analysis of variance (ANOVA). The results that pointed differences between the values were submitted to the test of multiple comparison of Tukey. In all cases, values were considered as significant if the $p$ value was $\leq 0.05$. For these analyses, we used the GraphPad Prism software version 5.0.

\section{Scanning electron microscopic analysis}

Young pupae infected with the strain MT of the $M$. anisopliae were fixed in $2.5 \%$ glutaraldehyde, $2.5 \%$ formaldehyde, and $0.05 \mathrm{M}$ sodium cacodylate buffer, $\mathrm{pH} 7.2$ for $72 \mathrm{~h}$, and post-fixed in $1 \%$ osmium tetroxide for $1 \mathrm{~h}$ in the same buffer. Samples were dehydrated in a graded series of ethanol and dried under liquid $\mathrm{CO}_{2}$ (CPD 030; Balzer Union). Specimens were mounted on supports and sputter-coated with a $20 \mathrm{~nm}$ layer of gold in the BALTEC (Sputter Coater - SCD 050) and finally investigated under scanning electron microscopy DSM 940A - Zeiss (NAP/MEPA-ESALQ/USP) operating in $20 \mathrm{KV}$.

\section{Light microscopic analysis}

Pupae from the group YP infected with the strain MT of $M$. anisopliae were fixed in the Bouin solution (Junqueira and Junqueira, 1983) on the first day every $6 \mathrm{~h}$ after the infection, and after this period, every $12 \mathrm{~h}$ until the 9th day (216 h). After being in the fixer for $24 \mathrm{~h}$, the material was subjected to dehydration and inclusion in paraffin according to the routine techniques of histology. Longitudinal cuts of $7 \mu \mathrm{m}$ of the material were obtained and the sections were stained with haematoxylin-eosin $(\mathrm{H} / \mathrm{E})$ and GomoriGrocott (Behmer et al., 1976). For photo-documentation of slides analyzed with Olympus light microscope, BX-50 was used as a digital 3CCD Pro-series with Image-Pro Plus version 4.5.1 (Media Cybernetics, Sao Paulo, Brazil).

\section{RESULTS AND DISCUSSION}

The mortality and abnormality rates in pupae of $D$. saccharalis of different ages treated with the two strains of $M$. anisopliae

As shown in Table 1, the mortality rate does not present any statistical difference among the groups studied with 
Table 1. Mortality and abnormality rates (\%) of Diatraea saccharalis pupae of different ages treated with strains of Metarhizium. anisopliae under laboratorial conditions.

\begin{tabular}{|c|c|c|c|c|c|c|}
\hline \multirow{2}{*}{$\begin{array}{c}\text { Group of } \\
\text { pupae }\end{array}$} & \multicolumn{2}{|c|}{ Control } & \multicolumn{2}{|c|}{ Strain MT } & \multicolumn{2}{|c|}{ Strain E9 } \\
\hline & MOT & AN & MOT & AN & MOT & AN \\
\hline PP & $0.00 \pm 0.00^{a}$ & $0.00 \pm 0.00 a$ & $100.0 \pm 0.00^{a}$ & $100.0 \pm 0.00 a$ & $100.0 \pm 0.00^{a}$ & $100.0 \pm 0.00^{a}$ \\
\hline YP & $0.00 \pm 0.00^{a}$ & $0.00 \pm 0.00^{\mathrm{a}}$ & $83.33 \pm 9.62^{\mathrm{a}}$ & $55.55 \pm 8.011^{b}$ & $77.77 \pm 5.55^{\mathrm{ab}}$ & $48.33 \pm 11.67^{b}$ \\
\hline OP & $0.00 \pm 0.00^{\mathrm{a}}$ & $0.00 \pm 0.00^{\mathrm{a}}$ & $77.77 \pm 5.55^{\mathrm{a}}$ & $65.00 \pm 5.00^{b}$ & $50.0 \pm 9.62^{b}$ & $44.44 \pm 5.55^{\mathrm{b}}$ \\
\hline
\end{tabular}

Mean followed by the standard error. Means that are followed by the same letter in the column do not differ statistically from each other according to Tukey's test ( $\mathrm{P} \leq 0.05)$. PP, Pre-pupae; YP, young pupae; OP, old pupae; MOT, mortality rate; AN, abnormality rate.

the strain $\mathrm{MT}(\mathrm{F}=3.25, \mathrm{df}=8, \mathrm{p}>0.05)$ and the abnormality rate is higher in the group $\mathrm{PP}(\mathrm{F}=18.45 \mathrm{df}=8, p<0.05)$. Regarding the strain E9, it presents higher mortality (less significant) and abnormality rates in the group PP $(F=15.25$, df $=8, p<0.05, F=17.28$, df $=8, p<0.05$, respectively). The mortality rate caused by strain MT ranged from 77.8 to $100.00 \%$ and that caused by strain E9 ranged from 50.00 to $100.00 \%$ among the studied groups, showing that pre-pupae group was the most sensitive for both strains of the fungus (Table 1). It was found that the effects of the infection of $M$. anisopliae in the maturation and reproduction of adults of Schistocerca gregaria (Orthoptera: Tettigoniidae) also depended on the age and time of inoculation of the pathogen (Blanford and Thomas, 2001). Adults of Blattella germanica (Blattodea: Blattellidae) are more susceptible to isolate ESALQ1037 of $M$. anisopliae infection than nymphs, since mortality of nymphs was always lower than that observed for adults at the same doses (Lopes and Alves, 2011). Ekesi and Maniania (2000) have indicated that the efficiency of $M$. anisopliae at the concentration of $1 \times 10^{8}$ conidia $\mathrm{mL}^{-1}$ is higher in adults than in larvae and pupae of Megalurothrips sjostedti (Thysanoptera: Thripidae). Thus, it can be mentioned that the susceptibility of insects to pathogenic fungi varies according to the stage of development as well as the tested strain (Ferron, 1985). It was observed that the abnormalities found in pre-pupae and pupae of different ages of $D$. saccharalis were related to the alteration in the integument (Figures $1 \mathrm{~A}, \mathrm{C}, \mathrm{F}$ and $\mathrm{G}$ ). The group PP showed tender cuticle with bright coloration, not presenting any signs of the process of sclerotization (Figure 1A). The other groups, YP and OP presented a totally wrinkled cuticle, with dry aspect and orifices (Figure 1C). This is in contrast to the changes in the larvae and adults of Thysanoptera, which presented an aberrant behavior of the legs and abdomen between three and four days of inoculation of $M$. anisopliae (Vestergaard et al., 1995).

\section{Longevity in young and old pupae of $D$. saccharalis from the emergence of adults obtained from infected pupae with two strains of $M$. anisopliae}

By observing the data in Table 2, it appears that the OP which probably has a short time to finish the metamorphosis from adult pupae has a statistically shorter longevity to the two strains of the pathogen than the control group $(\mathrm{F}=8.33, \mathrm{df}=8, p<0.05)$; this is different for the group YP that has not presented any difference in any strain in relation to the control $(F=0.62, d f=8$, $p>0.05$ ). The ecdysis has been reported as an important factor in the resistance of the insect during the fungus infestation, particularly, when the interval of time between the successive ecdysis is short (Vey and Fargues, 1977). This protective mechanism was proposed by Fargues (1972). After treating Anastrepha fraterculus (Diptera: Tephritidae) with M. anisopliae, Destéfano et al. (2005) achieved $86 \%$ reduction in larval, pre-pupae and pupae populations calculated from the emergence of adults. It was found that the application of Beauveria bassiana in the soil was effective in pupae of potato beetle (Coleoptera: Chrysomelidae), where there was a reduction of the emergence of adults from 74 to $77 \%$ (Watt and Lebrun, 1984).

Mortality between 40 and $100 \%$ are related in pea leafminer, Liriomya huidobrensis (Diptera; Agromyzidae) with isolates of $M$. anisopliae at five days after exposure (Migiro et al., 2010). The mortality of all adults of $D$. saccharalis occurred $24 \mathrm{~h}$ after the emergence and this led to $100 \%$ mortality that was achieved. After the death, signs of the mycelium growth and the conidiogenesis process were observed upon the corpses evidenced by the white and greenish colorations on the body surface, respectively. Corpses of adult were covered with spores of the fungus $48 \mathrm{~h}$ after the insect death $(216 \mathrm{~h}$ after the infection) (Figure $1 \mathrm{H}$ ).

\section{Morphological alterations in the cuticle of the pupae of $D$. saccharalis of different ages during the infection by $M$. anisopliae and extrusion of the pathogen}

The development of $M$. anisopliae was observed upon the pupae of $D$. saccharalis of different ages (Figure 1) and the pathogen presented a fast action in the group PP and subsequently, there was mycelium growth upon the integument after $48 \mathrm{~h}$ (Figure 1A). Longitudinal cuts in pupae of the group PP revealed that after $72 \mathrm{~h}$, the 

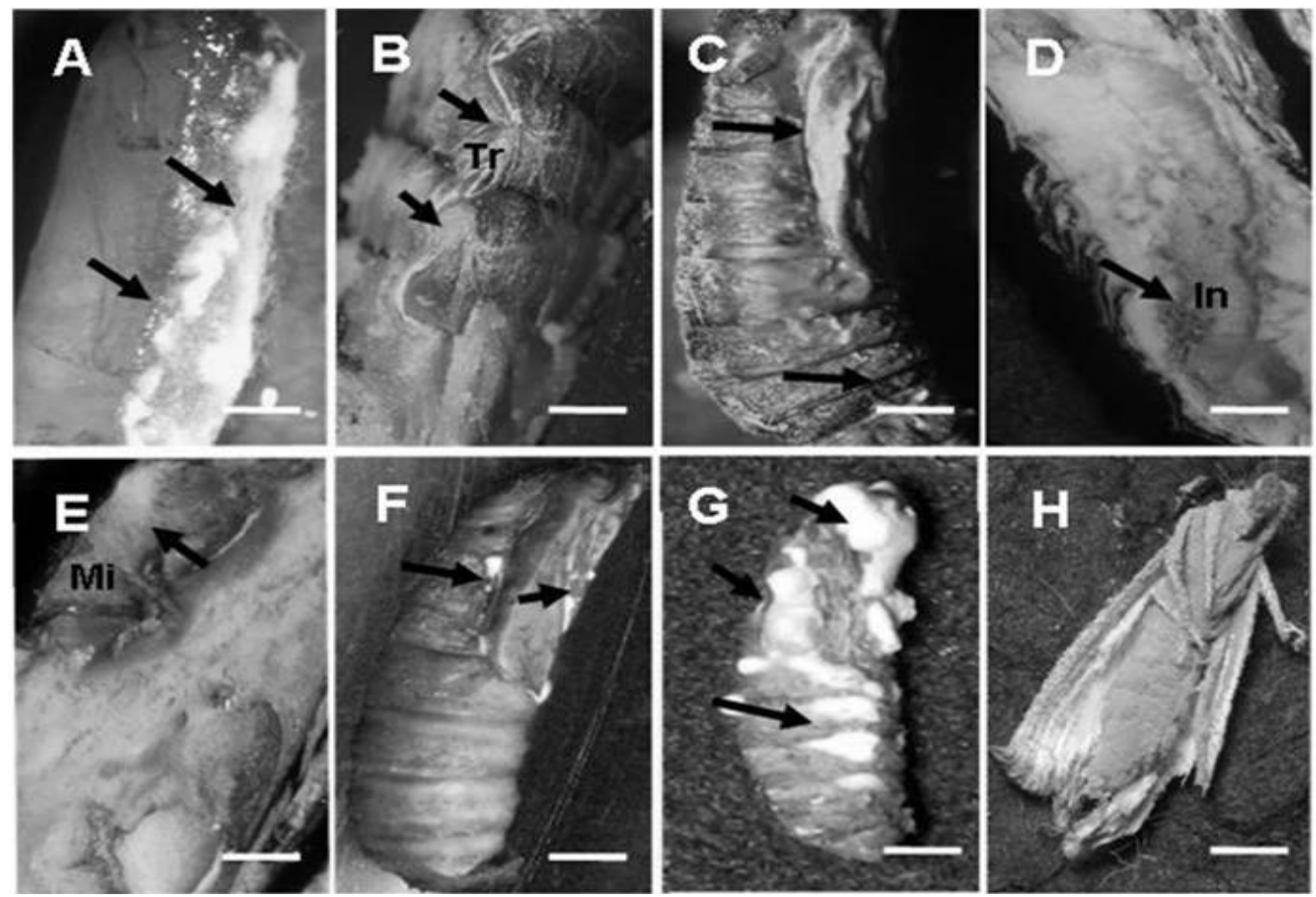

Figure 1. Development of MT strain of Metarhizium anisopliae on cuticle of pupae of Diatraea saccharalis of different ages in a stereomicroscopic analysis. A) PP group covered by the pathogen's mycelium (arrows) at the thoracic region. B) Interior of the integument of PP group evidencing the tracheas (arrows). C) Abnormality in the integument of YP an OP groups, the arrows indicate black spots and depressions in the cuticle. D) The arrow shows the sporulation of the pathogen in the digestive system, YP group. E) The arrow shows large amounts of hyphae pressing the cuticle, YP group. F) Beginning of the extrusion process, show a thorax intersegmental region (arrows), YP group. G) Extrusion process, the arrows show a large amount of hyphae at the intersegmental region (head), spiracles (thorax), and both (abdomen), YP group. H) Corpse of an adult emerged from a YP group. Tr, Trachea; In, intestine; Mi, mycelium. A, B, E, bar, $1 \mathrm{~mm}$; C to D, bar: $2 \mathrm{~mm}$ and F, G, H, bar: $3 \mathrm{~mm}$.

Table 2. Longevity (days) of young pupae and old pupae and the emergence rate (\%) of adults from young pupae and old pupae of Diatraea saccharalis treated with two strains of Metarhizium anisopliae under laboratorial conditions.

\begin{tabular}{lcccc}
\hline \multirow{3}{*}{ Treatment } & \multicolumn{4}{c}{ Group of pupae } \\
\cline { 2 - 5 } & \multicolumn{2}{c}{ Young pupae } & \multicolumn{2}{c}{ Old pupae } \\
\cline { 2 - 5 } & Longevity & Emergence & Longevity & Emergence \\
\hline Control & $9.00 \pm 0.00^{\mathrm{a}}$ & $100.0 \pm 0.00^{\mathrm{a}}$ & $5.66 \pm 0.44^{\mathrm{a}}$ & $100.0 \pm 0.00^{\mathrm{a}}$ \\
Strain MT & $7.16 \pm 0.83^{\mathrm{a}}$ & $11.11 \pm 5.55^{\mathrm{b}}$ & $3.16 \pm 0.60^{\mathrm{b}}$ & $22.22 \pm 5.55^{\mathrm{b}}$ \\
Strain E9 & $6.66 \pm 1.01^{\mathrm{a}}$ & $17.22 \pm 9.14^{\mathrm{b}}$ & $3.16 \pm 0.44^{\mathrm{b}}$ & $50.0 \pm 9.62^{\mathrm{b}}$ \\
\hline
\end{tabular}

Values are Mean \pm standard error. Means that are followed by the same letter in the column do not differ statistically from each other according to Tukey's test $(P \leq 0.05)$.

interior of the pre-pupae appeared empty, showing only the cuticle and tracheas (Figure 1B). It can be seen that the integument of the pre-pupae of $D$. saccharalis is more vulnerable to the penetration of pathogens through instar changes, since the new integument formed was not totally chitinized. The sclerotization propitiates a physical barrier, hardening considerably the integument as well as, a chemical barrier that makes the integument more stable through the pathogen enzymatic action (Alves and Pereira, 1998). The alteration in the host endocrine balance by $M$. anisopliae was found in adults of $S$. gregaria (Blanford and Thomas, 2001); however, in $D$. saccharalis, the changes observed in relation to the endocrine system were not assessed.

The structure of the cuticle of the young control pupae is shown in Figure 2A. The adhesion, germination of the 

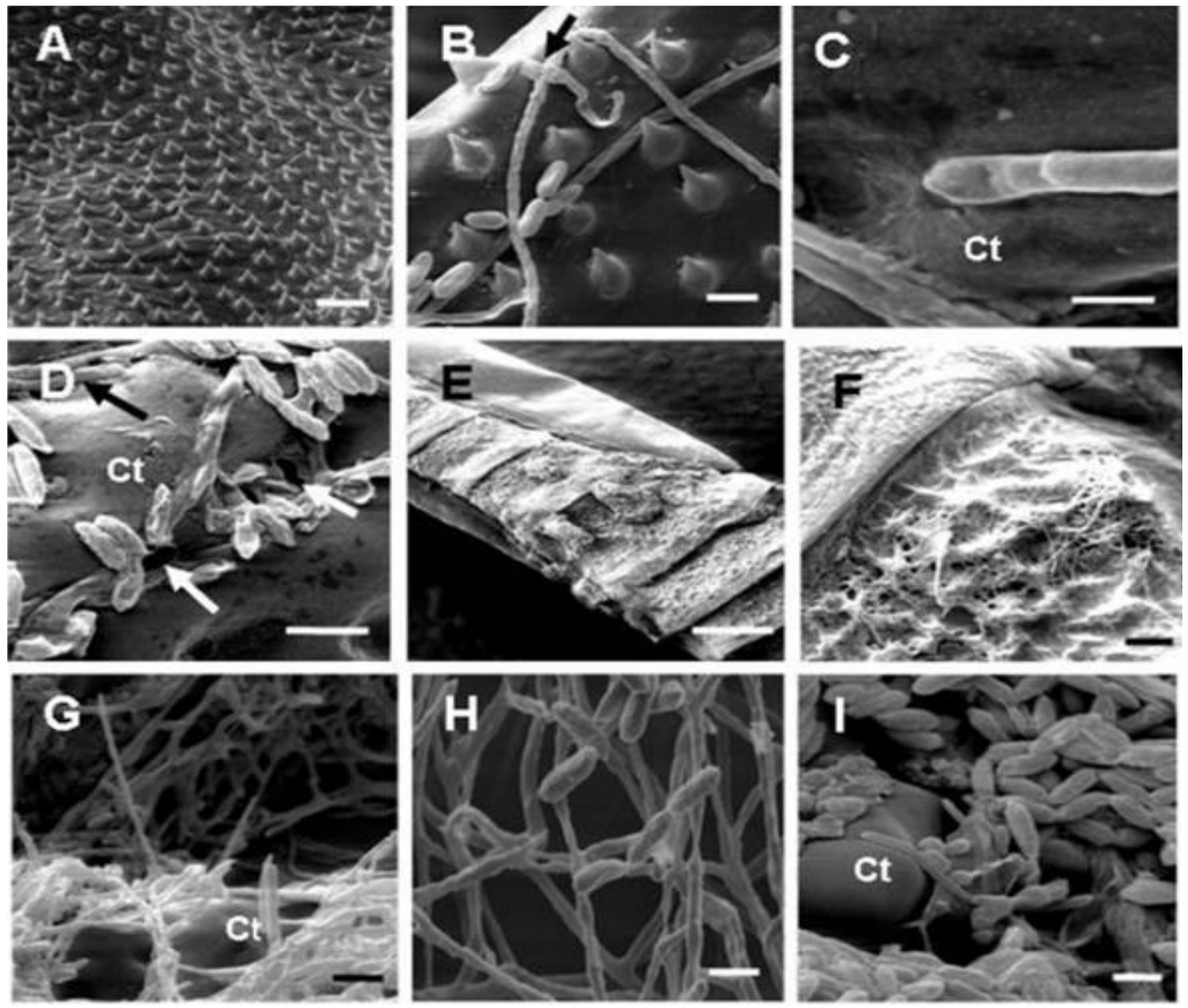

Figure 2. Scanning electron microscopic analysis showing alterations in the cuticle of young pupae of Diatraea saccharalis during the infection and extrusion processes by the MT strain of Metarhizium anisopliae. A) Detail of the surface of the control pupae cuticle, bar: $10 \mu \mathrm{m}$. B) Cuticle infected showing the germinative tube (arrow), bar: $50 \mu \mathrm{m}$. C) Detail of the appressorium forming a site of penetration, bar: $30 \mu \mathrm{m}$. D) The arrows show the orifices in the cuticle, bar 130: $\mu \mathrm{m}$. E) A general view of the thoracic region and abdomen in integument, bar: $300 \mu \mathrm{m}$. F) Detail of the thoracic region, bar: $500 \mu \mathrm{m}$. G) Development of the pathogen's mycelium upon the host's corpse, bar: $10 \mu \mathrm{m}$. H) Formation of conidiophores structures, bar: $50 \mu \mathrm{m}$. I) A corpse totally covered with spores, bar: $50 \mu \mathrm{m}$. Ct, Cuticle.

conidium and the development of the germinative tube on the pupae epicuticule were observed $18 \mathrm{~h}$ after the treatment with $M$. anisopliae (Figure 2B). The adhesion occurred probably through the hydrophobic interactions between the conidium and the cuticle of the insect -the production of a layer of adhesive mucus was observed. This extracellular mucilage has been believed to have a role in the support and transportation of enzymes that degrade the cuticle, besides being considered important for the growth of the hyphae and the formation of the appressorium (Zacharuk, 1970; Leger et al., 1991; Bidochka and Leger, 1997; Shahid et al., 2012).

Black spots and several depression sites were noticed in the cuticle of the groups YP and OP $24 \mathrm{~h}$ after the treatment with $M$. anisopliae (Figure 1C). These finding probably indicated the degradation of the epicuticle of the host caused by pathogens which entered through the sites of penetration (Vestergaard et al., 1999; Arruda et al., 2005; Zhang et al., 2010; Yan et al., 2011). The cuticle of the Galleria mellonela (Lepidoptera: Pyralidae) larvae infected with $M$. anisopliae and $B$. bassiana became black-spotted due to excessive melanization, indicating direct attack of the fungus on the defense system of the insects (Hussein et al., 2012).

An extensive hyphal growth and a formation of the appressorium with subsequent reaction of melanization in the tissue of the host were found in Culex quinquefasciatus (Diptera: Culicidae) (Lacey et al., 1988). A site of penetration from appressorium that was formed by the germination of the conidium $24 \mathrm{~h}$ after the infection is shown in Figure 2C. These structures seem to exert a mechanism of pressure on the host cuticle where several 
sites of depression are found as observed in the penetration site of the appressorium after $48 \mathrm{~h}$ of infection (Figure 2D). The mechanism of pressure may be followed by the enzymatic degradation with the deformation of the cuticle (Figures $2 \mathrm{E}$ and $\mathrm{F}$ ). It was found that the entomopathogenic fungus $M$. anisopliae produces several hydrolytic enzymes such as proteases, chitinases, and lipases in the host's cuticle during the infection process (Leger et al., 1987, 1996; Pinto et al., 1997; Tiago et al., 2002; Krieger et al., 2003; Beys et al., 2005; Shahid et al., 2012). According to Goettel et al. (1989), the penetration on the epicuticle initially happens with the enzymatic degradation and mechanic separation of the lamellae. Thus, it can be mentioned that the mechanism of mechanic pressure and the enzymatic degradation are the probable causes of the abnormalities developed in the integument of pupae of $D$. saccharalis during the infection process of $M$. anisopliae (Figures 1C, 2C, E and F).

In the treatment of Spodoptera littoralis (Lepidoptera: Noctuidae), larvae with five strains of entomopathogenic fungi was observed in the cuticle malformations, showing old and dark exuvium. Abnormal pupae attached with moth and fallen moth caused the pupal-moth intermediate stage (Amer et al., 2008). It was found that the colonization occurred between 48 and $120 \mathrm{~h}$ when the fungus attacked the interior of the insect before the extrusion (Figures 1D and E). After $96 \mathrm{~h}$ of infection, a large amount of mycelium could be noticed, this mechanically pressed the cuticle of the insect to help the emergence of the fungus (Figure 1E). After $120 \mathrm{~h}$ of infection, it was seen that the cuticle had breaks from the emergence of the fungus on the surface of the corpse (Figure 1F). Most advanced stage in the extrusion process after $144 \mathrm{~h}$ of infection (Figures $1 \mathrm{G}$ and $2 \mathrm{G}$ ). The extrusion process thus, caused great alterations in the host's cuticle probably through physical damages owing to the mycelium growth as well as the beginning of the sporulation process of the fungus (Alves, 1998).

It was observed that the breakage of the insect cuticle and the emergence of the pathogen to the surface (extrusion) began $120 \mathrm{~h}$ after the treatment with $M$. anisopliae (Figures $1 \mathrm{~F}$ and $\mathrm{G} ; 2 \mathrm{G}, \mathrm{H}$ and I). This process occurs only after the insect death and the hyphae started to emerge from the spiracles using the mechanical pressure through the weakest areas (intersegmental region) and later through the thicker cuticles; thus, the mycelium covers the surface of the whole corpse (Alves, 1998).

The stages of the mycelium of $M$. anisopliae covering the integument of the young pupae and consequently the sporulation upon the corpse between 120 and $192 \mathrm{~h}$ after the infection are shown in Figures $2 G$ to I from the beginning of the sporulation upon the corpse to the formation of conidiophore structures $168 \mathrm{~h}$ after the infection (Figure $2 \mathrm{H}$ ). It can be observed from the figure that the hyphae differentiated itself from the corpse forming several conidia in chains - these structures are denominated as conidiophores (Vicentini and Magalhães, 1996; Vestergaard et al., 1999; Alves et al., 2002; Garcia et al., 2005). A corpse was totally covered with spores of the fungus $192 \mathrm{~h}$ after the infection (Figure 2l).

\section{Morphological alterations in the internal tissues of young pupae of $D$. saccharalis during the colonization by $M$. anisopliae}

The colonization begins with the penetration process (Figure 2C), which occurs between 24 and $120 \mathrm{~h}$. During this process, the fungus secretes toxins, such as destruxin, which may affect the cells and the host reactions due to the production of $M$. anisopliae (Parry, 1995; Alves, 1998). After $48 \mathrm{~h}$ of infection, several vacuoles were found in the body of pupae of $D$. saccharalis. It was noticed in the magnified section that the vacuoles were located inside the fat body and the mycelium of $M$. anisopliae was present in the interiors (Figure 3D). The vacuoles were found in several insects parasitized with entomopathogenic fungi (Vestergaard et al., 1999; Sewify and Hashem, 2001; El-Sinary and Rizk, 2007). It was seen that the colonization of the tissues occurred rapidly in pupae of $D$. saccharalis, presenting the pathogen's mycelium in the fat body of the host in a matter of $60 \mathrm{~h}$ (Figure 3A). The process of colonization was also rapid in the hosts, Frankliniella occidentalis (Thysanoptera: Thripidae) and Rhammatocerus schistocercoides (Orthoptera: Acrididae) treated with $M$. anisopliae and Metarhizium flavoviride, respectively (Vicentini and Magalhães, 1996; Vestergaard et al., 1999). Normally, the hyphal growth was found to occur only after the insect death, penetrating in all tissues with filamentous hyphae. The fat body is one of the first organs colonized by the pathogen, which occurs $60 \mathrm{~h}$ after of the infection (Figure 3D). It is possible to observe the occurrence of disorganization in this tissue, which according to Alves (1998) affects the metamorphosis of the mature insect, leading to death.

It was seen that the lumen of the alimentary canal was totally occupied by the hyphae $60 \mathrm{~h}$ after the infection (Figures 1D and 3D) as described in $B$. germanica (Blattodea: Blattellidae) infected by Aspergillus flavus (Pathak and Kulshrestha, 1998). This vegetative growth in the digestive system causes a mechanic blockage in this organ, being one of the reasons for the insect death (Alves, 1998).

It was observed that the mycelium of $M$. anisopliae covers the entire host's body interior in $72 \mathrm{~h}$, forming a mass of hyphae (Figure 3B). In this period, the degradation of the pupa's tissues can be observed, probably by the action of the enzymes released by the fungus. The tissue lysis was also seen by Vestergaard et al. (1999) in the haemocel of $F$. occidentalis. The formation of structures denominated as chlamydospores 

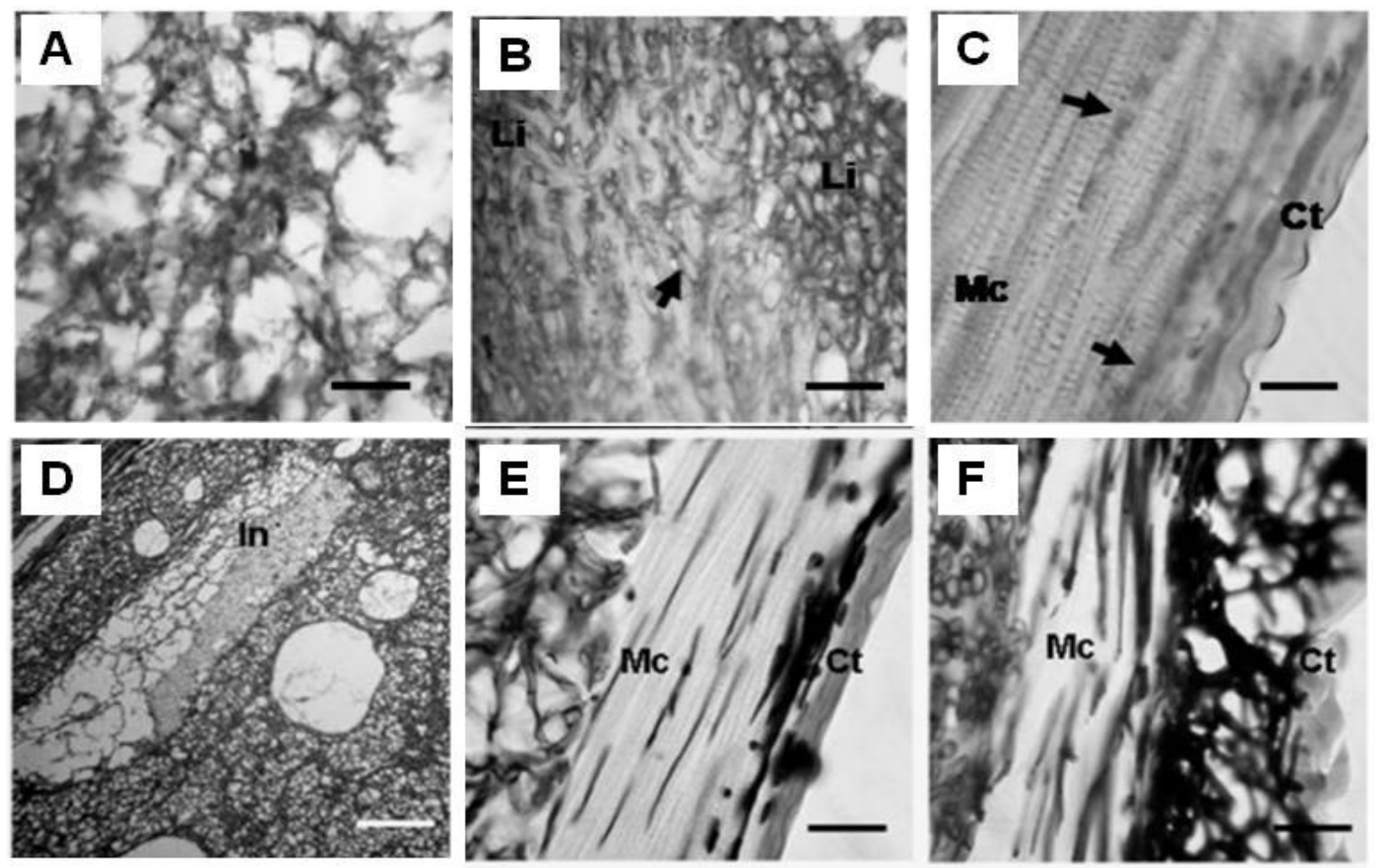

Figure 3. Morphological alterations in the internal tissues of young pupae of Diatraea saccharalis during the colonization by the MT strain of Metarhizium anisopliae in light microscopic analysis, haematoxylin-eosin (A, B and C) and Gomori-Grocott (D, E and F) staining. A) Detail of the fat body altered by the presence of the fungus. B) Detail of the abdominal region showing a mass of hyphae, the arrow points the structures denominated as chlamydospores, $100 \mathrm{X}$. C) The arrows indicate the presence of the fungus between the muscle fibres. D) Detail of the vacuoles and intestine with the presence of the hyphae. E) Muscle fibres with hyphae of the pathogens in the interior. F) Muscle fibres altered and separated. Ct, Cuticle; Vc, vacuole; Li, tissue lysis; Mc, musculature; In, intestine. A to C, bar: $160 \mu \mathrm{m}$; D, $80 \mu \mathrm{m}$; E to F, bar: $160 \mu \mathrm{m}$.

in this period as shown in Figure 3B was found in Galleria mellonella (Sewify and Hashem, 2001). These structures were also found as the preservation form of the fungus on the ground, possibly preserved inside the corpse (Zacharuk, 1973; Alves, 1998) and were affected by temperature and relative humidity within the eggs of tick (Ment et al., 2010).

The muscle tissue is one of the last tissues of $D$. saccharalis to be colonized by $M$. anisopliae, just before the emergence process, between 60, 72 and $96 \mathrm{~h}$ after the inoculation (Figure $3 \mathrm{C}, \mathrm{E}$ and $\mathrm{F}$, respectively). Deformation can be observed on the structures of muscle fibres, altering their composition as evidenced in the H/E staining (Figure $3 \mathrm{C}$ ). This mycelial growth is the cause of the lesions in the host's cuticle (Alves, 1998). As shown in Figures $3 \mathrm{E}$ and $\mathrm{F}$, inside the muscle fibre, the disorganization of the muscle and the growth of the mycelium in large scale among the musculature and the cuticle can be observed in adult planthopper (Toledo et al., 2010). This is probably due to the fact that the $M$. anisopliae, during its development, caused the separation of the muscle fibres and musculature from the cuticle, facilitating the mechanism of mechanic pressure in the cuticle of the pupae of $D$. saccharalis for its emergence.
The strains MT and E9 of the entomopathogenic fungus $M$. anisopliae are effective for causing mortality and significant abnormalities in pupae of $D$. saccharalis of different ages when compared to the control. The alterations in cuticle and internal tissues such as the digestive system, fat body, and muscle fibres during the infection, colonization and pathogen's emergence processes indicate the host death is an invasion of organs and probably fungal toxin.

\section{ACKNOWLEDGEMENTS}

We are grateful to CAPES (Brazilian National Council for Scientific and Technological Development) for their financial support and to NAP/MEPA/ESALQ/USP, for use of the scanning electron microscopy.

\section{REFERENCES}

Alves SB, Risco SH, Silveira NS, Machado NR (1984). Pathogenicity of nine isolates of Metarhizium anisopliae (Metsch.) Sorok. to Diatraea saccharalis (Fabr.). Zang. Entom. 97:403-406.

Alves SB, Pádua LEM, Azevedo EMVM, Almeida LC (1985). Control 
Drill cane sugar by the use of Beauveria bassiana. Pesq. Agrop. Bras. 20(4):403-406.

Alves SB (1998). Microbial control of insects. Publisher of the Foundation for Agrarian Studies Luiz de Queiroz Piracicaba. FEALQ. Entomopathogenic Fungi pp. 289-371.

Alves SB, Pereira RM (1998). Microbial control of insects. Publisher of the Foundation for Agrarian Studies Luiz de Queiroz Piracicaba. FEALQ. Physiological disorders caused by entomopathogens. pp. 39-53.

Alves SB, Rossi LS, Lopes RB, Tai MA, Pereira RM (2002). Beauveria bassiana yeast phase on agar medium and its pathogenicity against Diatraea saccharalis (Lepidoptera: Crambidae) and Tetranychus urticae (Acari: Tetranychidae). J. Invertebr. Pathol. 8:70-77.

Amer MM, El-Sayed TI, Bakheit HK, Moustafa SA, El-Sayed YA (2008). Pathogenicity and genetic variability of five entomopathogenic fungi against Spodoptera littoralis. Res. J. Agric. Biol. Sci. 4(5):354-367.

Ansari MA, Shah FA, Whittaker M, Prasad M, Butt TM (2007). Control of western flower thrips (Frankliniella occidentalis) pupae with Metarhizium anisopliae in peat and peat alternative growing media. Biol. Control 40:293-297.

Arruda W, Lübeck I, Schrank A, Vainstein MH (2005). Morphological alterations of Metarhizium anisopliae during penetration of Boophilus microplus ticks. Exp. Appl. Acarol. 37:231-244.

Bai NS, Sasidharan TO, Remadevi OK, Rajan PD, Balachander M (2010). Virulence of Metarhizium isolates against the polyphagous defoliator pest, Spilarctia obliqua (Lepidoptera; Arctiidae). J. Trop. Forest Sci. 22(1):74-80.

Behmer OA, Tolosa EMC, Freitas NAG (1976). (Eds.). Manual de técnicas para histologia normal e patológica. São Paulo: Edart, 256.

Beys da Silva WO, Mitidieri S, Schrank A, Vainstein MH (2005). Production and extraction of an extracellular lipase from the entomopathogenic fungus Metarhizium anisopliae. Process Biochem. 40:321-326

Bidochka MJ, St Leger RJ (1997). Mechanisms of Deuteromycete fungal infections in grasshoppers and locusts: an overview. Mem. Entomol. Soc. Can. 171:213-224.

Blanford S, Thomas MB (2001). Adult survival, maturation, and reproduction of the desert locust Schistocerca gregaria infected with the fungus Metarhizium anisopliae var. acridum. J. Invertebr. Pathol. $78: 1-8$.

Destéfano RHR, Brechara IJ, Messias CL, Piedrabuena AE (2005). Effectiveness of Metarhizium anisopliae against immature stages of Anastrepha fraterculus fruitfly (Diptera; Tephritidae). Braz. J. Microbiol. 36:94-99.

Ekesi S, Maniania NK (2000). Susceptibility of Megalurothrips sjostedti developmental stages to Metarhizium anisopliae and the effects of infection on feeding, adult fecundity, egg fertility and longevity. Entomol. Exp. Appl. 94:229-236.

El-Sinary NH, Rizk SA (2007). Entomopathogenic fungus, Beauveria bassiana (Bals.) and gamma irradiation efficiency against the greater wax moth, Galleria melonella (L.). Am-Eurasian J. Sci. Res. 2:13-18.

Fargues J (1972). Etude des conditions d'infection des larves doryphore, Leptinotarsa decemlineata Say, par Beauveria bassiana (Bals.) Vuill. (Fungi Imperfecti). Entomophaga 17:319-337.

Ferron P (1978). Biological control of pests by entomopathogenic fungi. Annu. Rev. Entomol. 23:409-442.

Ferron P (1985). Fungal control. In: G.A. Kerkut, L.L. Gilbert (eds). Comparative insect physiology, Biochemistry and Pharmacology. Pergamon Press, Oxford. 12:313-346.

Garcia MV, Monteiro AC, Szabo MJP, Prett N, Bechara GH (2005). Mechanism of infection and colonization of Rhipicephalus sanguineus eggs by Metarhizium anisopliae as revealed by scanning electron microscopy and histopathology. Braz. J. Microbiol. 36:368-372.

Goettel MS, St Leger RJ, Rizzo NW, Staples RC, Roberts W (1989). Ultrastructural localization of a cuticle-degrading protease produced by the entomopathogenic fungus Metarhizium anisopliae during penetration of host (Manduca sexta) cuticle. J. Gen. Microbiol. 135:2233-2239.

Guagliumi P (1973). Pragas da cana-de-açúcar: Nordeste do Brasil. Divulgação do M.I.C, Instituto do Açúcar e Álcool, Coleção Canavieira n. 10, Rio de Janeiro. 622 p.

Hajek AE, St Leger RJ (1994). Interaction between fungal pathogens and insect hosts. Annu. Rev. Entomol. 39:293-322.

Hegedus DD, Khachatourians GG (1996). Analysis of cellular defense reactions of the migratory grasshopper, Melanoplus sanguinipes, infected with geat sensitive mutans of Beauveria bassiana. J. Invertebr. Pathol. 68:166-169.

Hensley SD, Hammond AM (1968). Laboratory techniques for rearing the sugarcane borer on an artificial diet. J. Econ. Entomol. 61:17421743.

Hussein KA, Abdel-Rahman MAA, Abdel-Mallek AY, El-Maraghy SS, Joo JH (2012). Pathogenicity of Beauveria bassiana and Metarhizium anisopliae against Galleria mellonella. Phytoparasitica 40:117-126.

Junqueira LCU, Junqueira LMMS (1983). Técnicas básicas de citologia

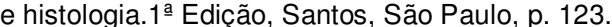

Krieger CM, Schrank A, Vainstein MH (2003). Regulation of extracellular chitinases and proteases in the entomopathogen and acaricide Metarhizium anisopliae. Curr. Microbiol. 46:205-210.

Lacey CM, Lacy LA, Roberts DR (1988). Route of invasion and histopathology of Metarhizium anisopliae in Culex quinquefascialus. J. Invertebr. Pathol. 52:108-118.

Leger RJ, Cooper RM, Charnley AK (1987). Production of cuticledegrading enzymes by the entomopathogen Metarhizium anisopliae during infection of cuticles from Calliphora vomitoria and Manduca sexta. J. Gen. Microbiol. 133:1371-1382.

Leger RJ, Goettel M, Roberts DW, Staples RC (1991). Penetration events during infection of host cuticle by Metarhizium anisopliae. J. Invertebr. Pathol. 58:168-179.

Leger RJ, Joshi L, Bidochka MJ, Rizzo NW, Roberts DW (1996). Characterization and ultrastructural localization of chitinases from Metarhizium anisopliae, M. flavoviride, and Beauveria bassiana during fungal invasion of host (Manduca sexta) cuticle. Appl. Environ. Microbiol. 62:907-912.

Lopes RB, Alves SB (2011). Differential susceptibility of adults and nymphs of Blattella germanica (L.) (Blattodea: Blattellidae) to infection by Metarhizium anisopliae and assessment of delivery strategies. Neotrop. Entomol. 40:368-374

Ment D, Gindin G, Glazer I, Perl S, Elad D, Samish M (2010). The effect of temperature and relative humidity on the formation of Metarhizium anisopliae chlamydospores in tick eggs. Fungal Biol. 114:49-56.

Migiro LN, Maniania NK, Chabi-Olaye A, Vandenberg J (2010). Pathogenicity of entomopathogenic fungi Metarhizium anisopliae and Beauveria bassiana (Hypocreales: Clavicipitaceae) isolates to the adult Pea leafminer (Diptera; Agromyzidae) and prospects of an autoinoculation device for infection in the field. Environ. Entomol. 39:468-475.

Parry M (1995). A review of mycochemical and insect interactions. Biocontrol News Inform. 16:27-33.

Pathak XC, Kulshrestha V (1998). Experimental aspergillosis in the German cockroach Blattella germanica: a histopathological study. Mycopathologia 143:13-16.

Pinto AS, Barreto CC, Schrank A, Ulhoa CJ, Vainstein MH (1997). Purification and characterization of an extracellular chitinase from the entomopathogenic Metarhizium anisopliae. Can. J. Microbiol. 43:322327.

Pontecorvo G, Roper JA, Hemmons LM, Macdonald KD, Bufton AWJ (1953). The genetics of Aspergillus nidulans. Adv. Genet. 5:141-238.

Revathi N, Ravikumar G, Kalaiselvi M, Gomathi D, Uma C (2011). Pathogenicity of three entomopathogenic fungi against Helicoverpa armigera. J. Plant. Pathol. Microbiol. 2:1-4.

Roc RM, Hammond Jr. AM, Reagan TE, Hensley SD (1981). A Bibliographyof the Sugarcane Borer, Diatraea saccharalis (Fabricius), 1887-1980. U.S. Agricultural Research Service (Southern Region), U.S. Department of Agriculture, New Orleans. p. 101.

Sewify GH, Hashem MY (2001). Effect of the entomopathogenic fungus Metarhizium anisopliae (Metsch.) Sorokin on cellular defence response and oxygen uptake of the wax moth Galleria mellonella L. (Lep., Pyralidae). J. Appl. Entomol. 125:533-536.

Shahid AA, Qayyumrao A, Bakhsh A, Husnain T (2012). Entomopathogenic fungi as biological controllers: New insights into their virulence and pathogenicity. Arch. Biol. Sci. 64(1):21-42.

Tiago PV, Fungaro MHP, Furlaneto MC (2002). Cuticle-degrading proteases from the entomopathogen Metarhizium flavoviride and their distribuition in secreted and intracellular fractions. Lett. Appl. 
Microbiol. 34:91-94.

Toledo AV, Remes Lenicov AMM, López LCC (2010). Histopathology caused by the entomopathogenic fungi, Beauveria bassiana and Metarhizium anisopliae, in the adult planthopper, Peregrinus maidis, a maize virus vector. J. Insect Sci. 10:35

Vestergaard S, Gillespie AT, Butt TM, Schreiter G, Eilenberg J (1995). Pathogenicity of the hyphomycete fungi Verticillium lecanii and Metarhizium anisopliae to the western flower thrips, Frankliniella occidentalis. Biocontrol Sci. Technol. 5:185-192.

Vestergaard S, Butt TM, Gillespie AT, Eilenberg J (1999). Light and electron microscopy studies of the infection of the western flower thrips Frankliniella occidentalis (Thysanoptera: Thripidae) by the entomopathogenic fungus Metarhizium anisopliae. J. Invertebr. Pathol. 73: 25-33.

Vey A, Fargues J (1977). Histological and ultrastructural studies of Beauveria bassiana infection in Leptinotarsa decemlineata Say larvae during ecdysis. J. Invertebr. Pathol. 30:207-215.

Vicentini S, Magalhães P (1996). Infection of the grasshopper, Rhammatocerus schistocercoides Rehn by the entomopathogenic fungus, Metarhizium flavoviride Gams \& Rozsypal. Ann. Soc. Entomol. Brasil. 25:309-314.
Watt BA, Lebrun RA (1984). Soil effects of Beauveria bassiana on pupal populations of the Colorado potato beetle (Coleoptera: Chrsomelidae). Environ. Entomol. 13:15-18.

William JR, Metcalfe JR, Mungomery RW, Mathes R (1969). Pests of Sugar Cane. Elsevier Publ. Co., New York, N.Y. 568 p.

Yan H, Wang D, Zhao X, Huang D, Mai X (2011). Observation of the infection process of Metarhizium anisopliae on the cuticle of Anoplophora glabripennis larvae with scanning electron microscopy. Front. Agric. China 5(4):662-665.

Zacharuk RY (1970). Fine sctructure of the fungus Metarhizium anisopliae infecting three species of larval Elateridae (Coleoptera). III. Penetration of the host integument. J. Invertebr. Pathol. 15:372-396.

Zacharuk RY (1973). Electron-microscope studies of the histopathology of fungal infections by Metarhizium anisopliae. Misc. Publ. Entomol. Soc. Am. 9:112-119.

Zhang X, Yang Y, Zhang L (2010). Ultrastructure of the entomopathogenic fungus Metarhizium anisopliae during cuticle penetration in the Locust migratoria (Insecta: Acrididae). J. Orthoptera Res. 19:115-119. 